\title{
Third record of Rhodnius amazonicus and comparative study with $R$. pictipes (Hemiptera, Reduviidae, Triatominae)
}

\author{
João Aristeu da Rosa ${ }^{\mathrm{a}, *}$, Eder Santos Souza ${ }^{\mathrm{a}}$, Adelson da Costa Teixeira ${ }^{\mathrm{b}}$, \\ Rosenildo Ribeiro Barbosa ${ }^{\mathrm{b}}$, Aecildo José de Souza ${ }^{\mathrm{b}}$, Tiago Belintani ${ }^{\mathrm{c}}$, \\ Juliana Damieli Nascimento ${ }^{c}$, Hélcio Reinaldo Gil-Santana ${ }^{\mathrm{d}}$, Jader de Oliveira ${ }^{\mathrm{a}}$ \\ a Departamento de Ciências Biológicas, Faculdade de Ciências Farmacêuticas, Universidade Estadual Paulista (UNESP), Araraquara, 14800-903 SP, Brazil \\ b Secretaria Estadual de Saúde-8, Centro Regional de Saúde, Breves, 68800-000, PA, Brazil \\ c Departamento de Parasitologia, Instituto de Biologia, Universidade Estadual de Campinas, Campinas, 13083-862, SP, Brazil \\ d Laboratório de Diptera, Instituto Oswaldo Cruz, Rio de Janeiro, 21040-360, RJ, Brazil
}

\section{A R T I C L E I N F O}

\section{Keywords:}

Rhodnius amazonicus

Rhodnius pictipes

Identification

Measurement

Scanning

\begin{abstract}
A B S T R A C T
Rhodnius amazonicus Almeida et al. (1973) is a triatomine of rare occurrence. This species was found for the third time in Breves city, Pará state, Brazil. Morphometric and morphological studies were carried out on one male and one female. Lent and Wygodzinsky (1979) considered this species as a synonym of $R$. pictipes, until its revalidation after 23 years by Bérenger and Pluot-Sigwalt (2002). Considering the synonym mentioned above, a comparative study between these two species was performed in order to report the third encounter of this species, and increase the number of morphological characters that distinguish $R$. amazonicus from $R$. pictipes. The dorsal side of the head, the dorsal and ventral portions of the thorax, the dorsal, ventral and posterior sides of the female genitalia, eggs and the median process of the pygophore were examined by scanning electronic microscopy (SEM). The head, thorax, abdomen and egg parameters of these two species were also measured. The identification of characters on the head, stridulatory sulcus, mesosternum, metasternum, scutellum, process of urotergite I, external female genitalia, pygophore and eggs made the distinction between $R$. amazonicus and $R$. pictipes possible. This study has shown the new characters recorded and described for the first time for $R$. amazonicus and $R$. pictipes by SEM here made it possible to confirm the morphological separation between these two species. The morphometric analysis also confirmed that the above two taxa are different at specific level.
\end{abstract}

\section{Introduction}

The article published by Chagas (1909) describing the protozoan Trypanosoma cruzi and the epidemiological chain of American trypanosomiasis provided a significant advance in Triatominae studies (Chagas, 1909; Pinto, 1927). A parameter that can be used to evaluate this statement is that, beginning with the description of Cimex rubrofasciatus (currently, Triatoma rubrofasciata) by De Geer (1773), the number of described Triatominae rose to 59 species until 1907, but only 33 of them remained as valid (Lent and Wygodzinsky, 1979). However, just 17 years after the discovery of their medical importance, there were already 62 recognized species included in this group (Pinto, 1926), most of which still valid today.

While Lent and Wygodzinsky (1979) recognized 111 species of these vectors as valid, currently the subfamily Triatominae comprises 18 genera and 152 species (Galvão, 2014; Mendonça et al., 2016; Rosa et al., 2017). However, not all triatomine species have been studied in detail, either because their low epidemiological relevance (e.g. species of Psammolestes Bergroth, 1911) or because they have been recently discovered (R. zeledoni Jurberg et al., 2009; R. marabaensis Souza et al., 2016, $R$. taquarussuensis Rosa et al., 2017) or even for their rarity, such as $R$. paraensis Sherlock et al. (1977). Because of its rarity, there are only four publications including descriptions of the morphological characters of Rhodnius amazonicus (Almeida et al., 1973; Lent and Wygodzinsky, 1979; Bérenger and Pluot-Sigwalt, 2002; Galvão, 2014), this one being the fifth. Almeida et al. (1973) relied on the finding of a single female specimen, which was captured with light bait on October 24, 1965 in the Manaus-Itacoatiara road, Manaus city, Amazonas state, Brazil. The holotype of this species was deposited in the Parasitology Laboratory of INPA (National Institute of Amazonian Studies).

Although Almeida et al. (1973) had firstly considered the specimen to be $R$. pictipes Stål 1872, after a careful examination, they concluded

\footnotetext{
* Corresponding author at: Faculdade de Ciências Farmacêuticas (UNESP), Rodovia Araraquara-Jaú, km 1, 14800-903, Araraquara, SP, Brazil.

E-mail address: joaoaristeu@gmail.com (J.A. da Rosa).
} 

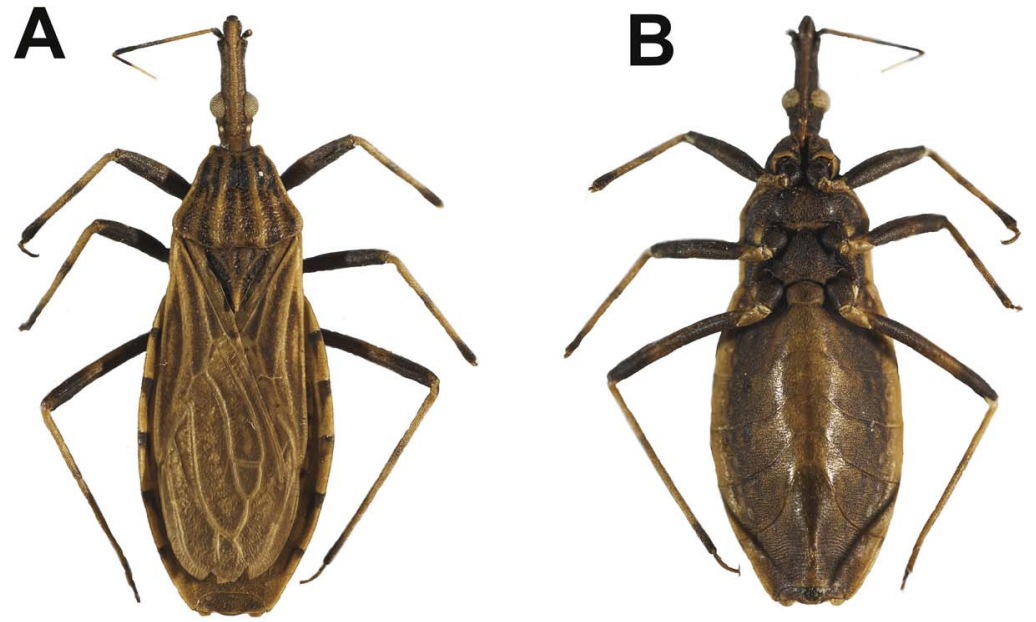

Fig. 1. $R$. amazonicus female. A- dorsal side; B- ventral side; $R$. pictipes female. C- dorsal side; D- ventral side.

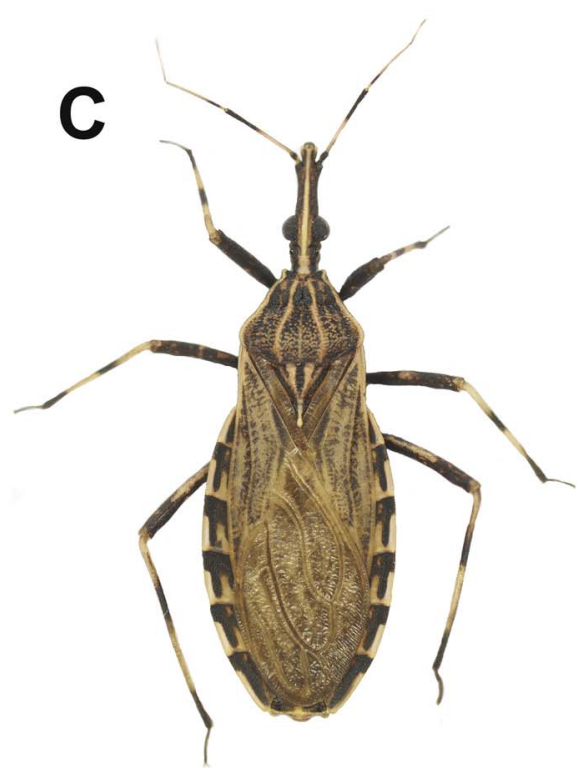

that it was a new species, $R$. amazonicus. Lent and Wygodzinsky (1979) did not consider $R$. amazonicus as a valid species, but they reached that conclusion without examining the holotype and relying on a comparative study based on photographs. Furthermore, they mentioned that they did not find the differences reported by the authors of the taxon (Almeida et al., 1973). Additionally, because the only female considered to be $R$. amazonicus was collected with several $R$. pictipes specimens, the validity of the new species was questioned, leading to the conclusion that the holotype of $R$. amazonicus was an abnormal, poorly preserved specimen of $R$. pictipes (Lent and Wygodzinsky, 1979). However, in 2002, after finding an atypical couple among 100 specimens of $R$. pictipes collected in French Guiana, Bérenger and PluotSigwalt (2002) revalidated $R$. amazonicus.

In this article, a male and a female of $R$. amazonicus found in Breves, Pará, were compared with males and females of $R$. pictipes maintained in a laboratory colony. The present study confirms and provides additional differences of characters between $R$. amazonicus and $R$. pictipes verified by the descriptors and revalidators (Almeida et al., 1973; Bérenger and Pluot-Sigwalt, 2002).

The terminology mainly follows Lent and Wygodzinsky (1979).

\section{Material and methods}

In July 2015, during a careful examination of dead triatomine specimens from the Entomology Laboratory of the Eighth Regional Health Center, Breves, Pará state, Brazil, among several specimens identified as $R$. pictipes, a couple with distinct features remained unidentified at first. In the Parasitology Laboratory of the Department of Biological Sciences of the Faculty of Pharmaceutical Sciences, UnespAraraquara, upon consultation of the key to Rhodnius species belonging to the pictipes group presented by Bérenger and Pluot-Sigwalt (2002), the unknown couple was finally identified as $R$. amazonicus and studied here (Figs. 1 A,B, 2 A,B ).

The specimens of $R$. pictipes used in the present study were obtained from colonies kept at the Triatominae Insectarium of the Faculty of Pharmaceutical Sciences, São Paulo State University (Unesp/ Araraquara, Triatominae Colonies of Araraquara - CTA 072) (Figs. 1 C,D, 2 C,D). The first specimens of this colony were received from the Evandro Chagas Institute, Belém, Pará state, Brazil, on January 18, 1998.

Eighteen characters of ten females and sixteen characters of ten males of $R$. pictipes (Table 1) were analyzed, as well as, seventeen characters of the female specimen and thirteen characters of the male specimen of $R$. amazonicus, in view of the absence of antennal segments (Rosa et al., 2010; Souza et al., 2016). Length and opercular opening of two eggs of $R$. amazonicus and thirty eggs of $R$. pictipes were measured (Table 1 ). The eggs of $R$. amazonicus were obtained by opening the abdomen to study the external female genitalia. We report that this is the second time we have studied eggs obtained from the ovaries of females. Variations between the parameters analyzed were estimated by Student's $t$-test, and values were calculated using the GraphPad Prism software (version 5.00, Windows, GraphPad Software, San Diego, 


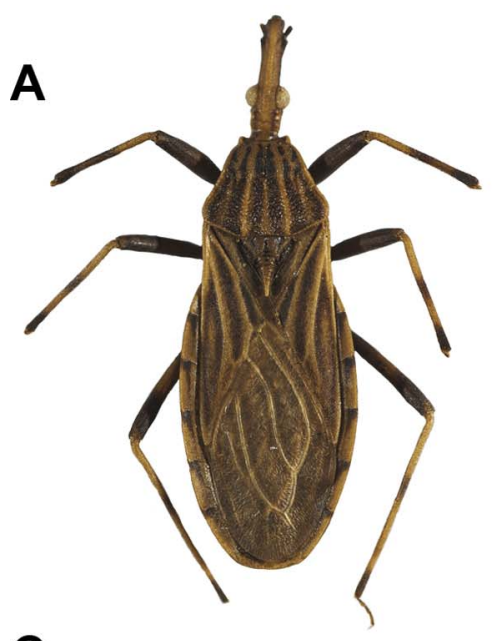

C

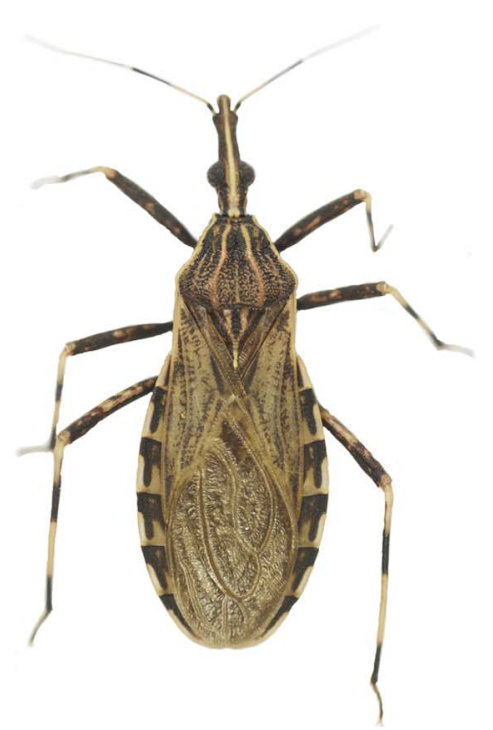

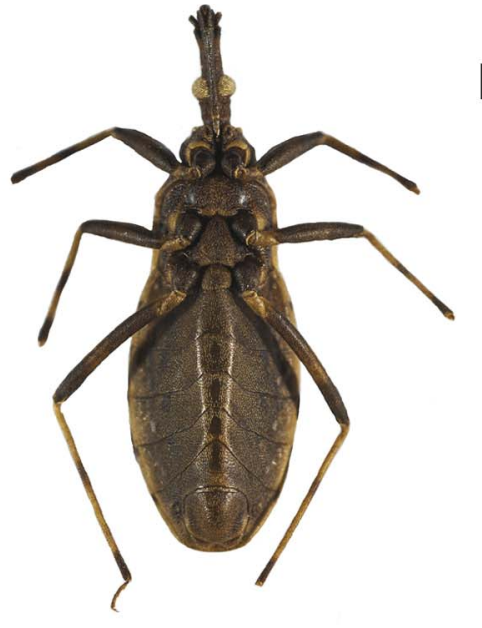

Fig. 2. $R$. amazonicus male. A- dorsal side; B- ventral side; R. pictipes B male. C- dorsal side; D- ventral side.

Table 1

Mean of measurement (mm) of specimens of Rhodnius amazonicus and Rhodnius pictipes, eggs, females and males.

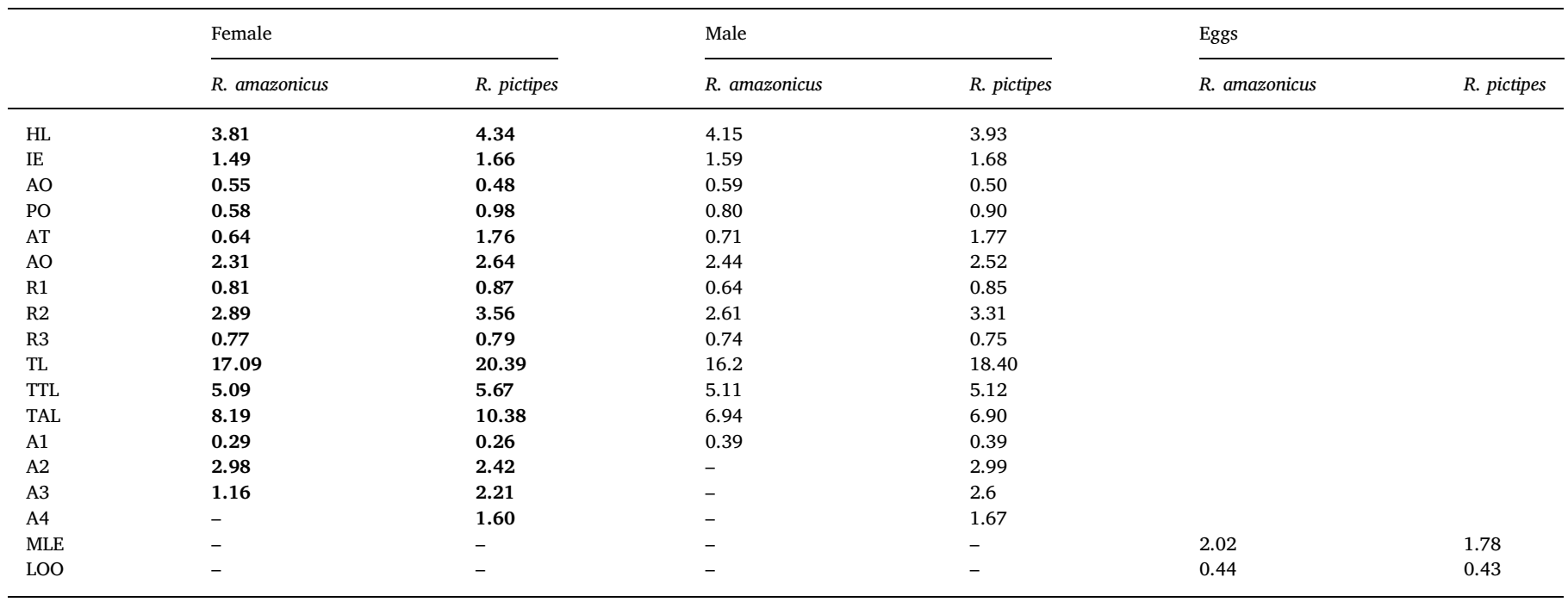

HL, head length; IE, inner distance between eyes; AO, anteocular distance; PO, postocular distance (excluding neck); AT, Distance between Antenniferous tubercles and Clypeus;AO, AnteOcular Distance, R1, R2, and R3, lengths of first, second, and third rostral segments, respectively; TL, Total length of the Triatominae; TTL, Total Thorax Length; TAL, Total Abdomen Length; A1, A2, A3 and A4, 1st, 2nd, 3rd, and 4th antennal segments, MLE - maximum length of egg, LOO - length of the opercular opening, respectively. The values in bold were significant at $\alpha=0.05$, using unpaired $t$-test. 

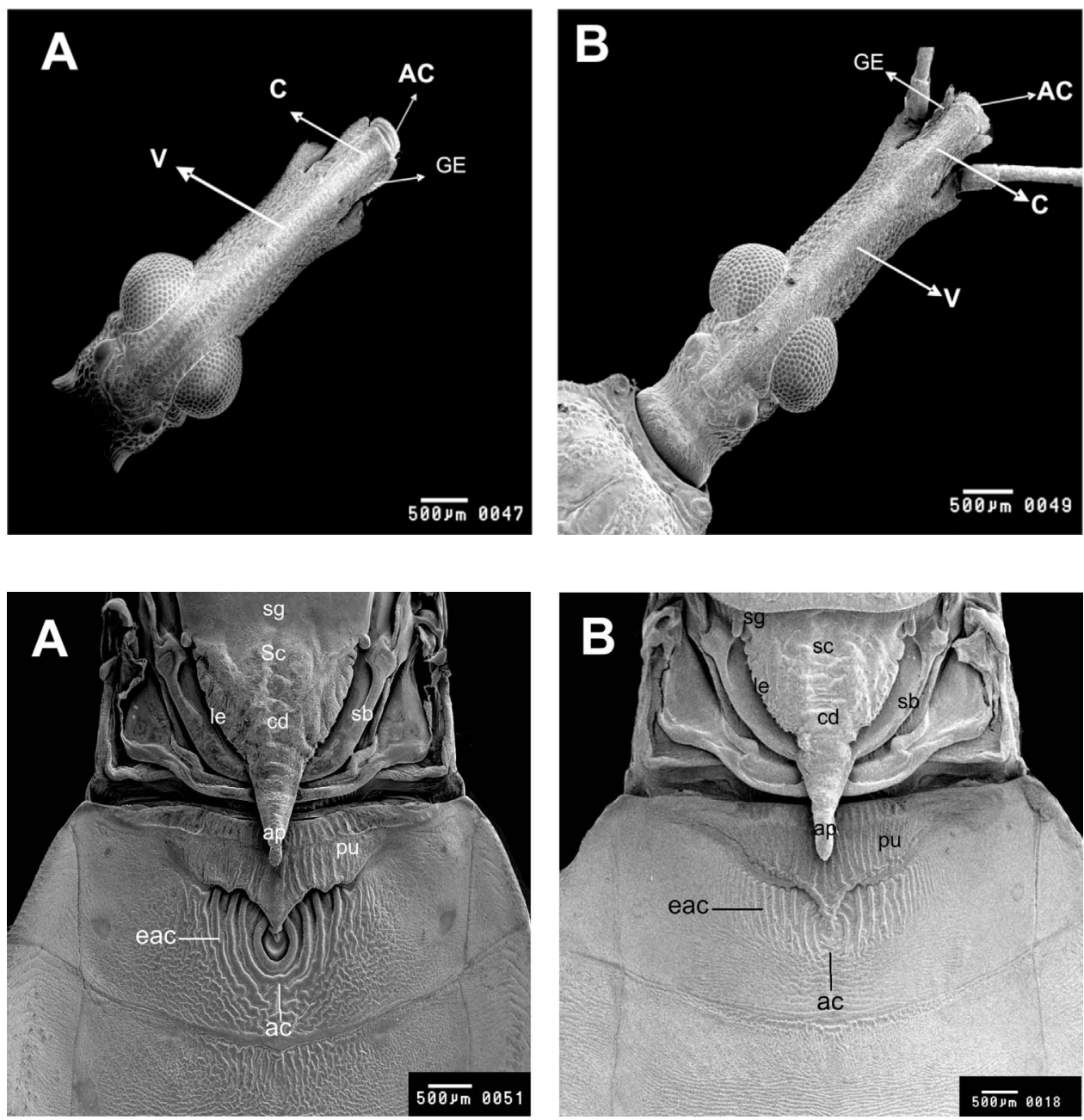

Fig. 3. Head for dorsal view by SEM. A- R. amazonicus; B- R. pictipes. V: vertex; C: clypeus; AC: anticlypeus; GE: gena.

\section{California).}

In the morphological studies, two females, one of $R$. amazonicus and one of $R$. pictipes, were analyzed using scanning electron microscope (SEM). The characters studied were the dorsal portion of the head, ventral and dorsal portion of the thorax, and the dorsal, ventral and posterior portions of the external female genitalia, as well as eggs and the male pygophore similarly as done in the work of Souza et al. (2016). Images were obtained from a stereoscopic microscope Leica MZ APO and Motic Images Advanced software, version 3.2, and SEM under a Topcon SM-300 microscope.

\section{Results}

\subsection{Morphological remarks - Rhodnius amazonicus Almeida et al., 1973}

Material examined - BRAZIL: Pará: Breves: 140'41.6"S, $50^{\circ} 28^{\prime} 46.3^{\prime \prime} \mathrm{W}$, deposited in Triatominae Collection Dr. José Maria Soares Barata of the São Paulo State University (UNESP), School of Pharmaceutical Sciences, Araraquara ( $1 \sigma^{\prime} 1$ \& $)$.

Rhodnius pictipes Stål, 1872

Material examined - BRAZIL: Pará: Belém: Colony from Instituto Evandro Chagas, initiated on January 18 of 1998, deposited at Insectarium Triatomine of the São Paulo State University (UNESP), School of Pharmaceutical Sciences, Araraquara (15 $\sigma^{\Upsilon} 15$ ) ).

\subsection{General morphological remarks of Rhodnius amazonicus}

Total length: male: $16.2 \mathrm{~mm}$, female: $17.9 \mathrm{~mm}$. General color yellowish brown, with scattered dark spots, appearance not mottled. Head: integument slightly granulose; general coloration brownish with a yellow brownish longitudinal band on anteocular region, dorsally.

Anterior and lateral margins of the pronotum with yellowish carenas. Pronotum: fore lobe with six irregular dark bands; hind lobe with six dark longitudinal bands and $1+1$ yellowish submedian carenas and integument granulose. Hemelytra do not reach the extremity of the abdomen in the female. Connexivum yellowish, with a triangular black spot on each segment. (Figs. 1 A,B, 2 A,B).

\subsection{Comparative features between $R$. amazonicus and R. pictipes}

\subsubsection{Head}

Rhodnius amazonicus: central longitudinal portion of the head slightly delimited with a pair of glabrous stripes; clypeus delimited; larger genae; anteclypeus convex (Fig. 3A). Rhodnius pictipes: the head is larger and the central longitudinal portion is not delimited by glabrous lines; smaller genae with the posterior portion more lager anteclypeus straight (Fig. 3B).

\subsubsection{Thorax}

The terminal portion of the scutellum of $R$. amazonicus (Fig. 4A) is round-shaped, whereas on $R$. pictipes (Fig. 4B) it is tapered. There are two $(1+1)$ lateral strangulations at the median portion of the scutellum of $R$. pictipes (Fig. 4B) while the scutellum of $R$. amazonicus does not possess such markings (Fig. 4A).

The stridulatory sulcus of R.amazonicus (Fig. 5A) is shorter and wider, whereas in $R$. pictipes it is longer and thinner (Fig. 5C). Between 

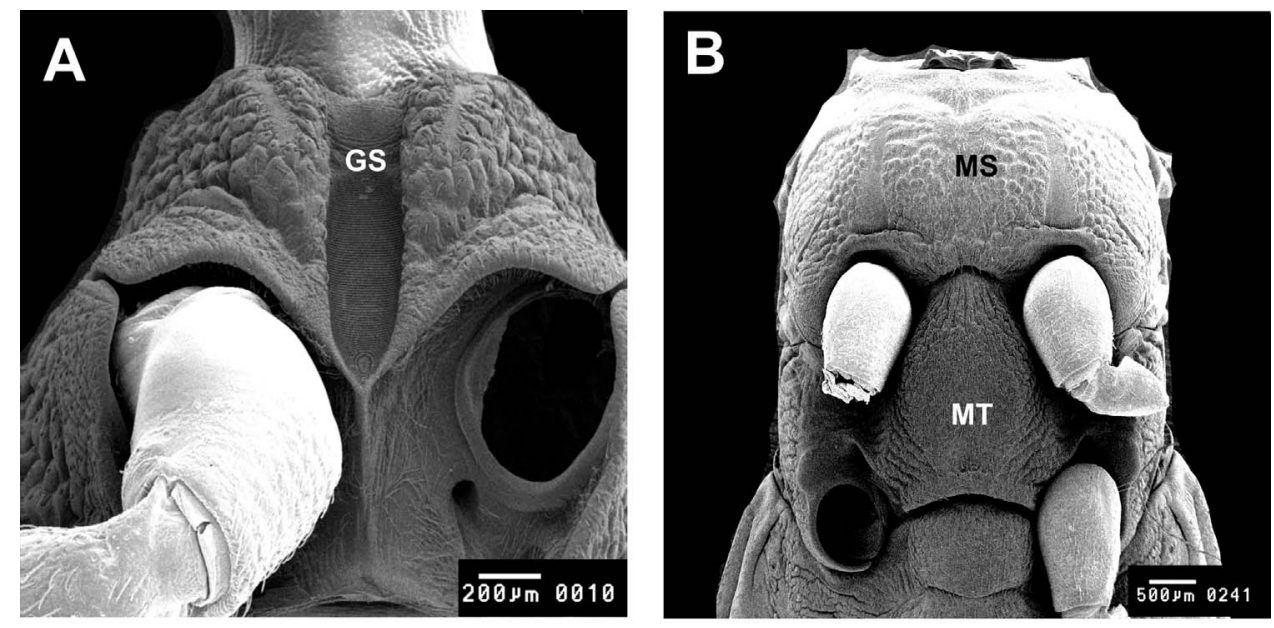

Fig. 5. Thorax ventral view by SEM. A,B- R. amazonicus; C,D- $R$. pictipes. GS: stridulatory groove; MS: mesosternum; MT: metasternum.
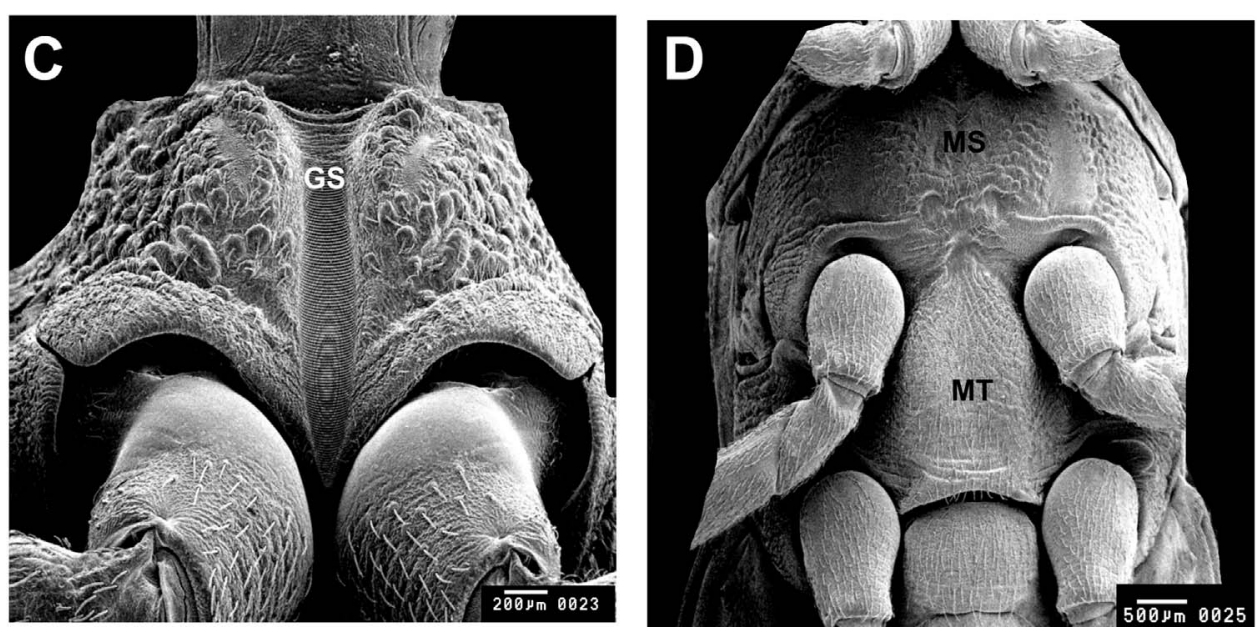

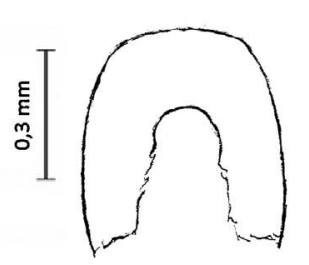

A

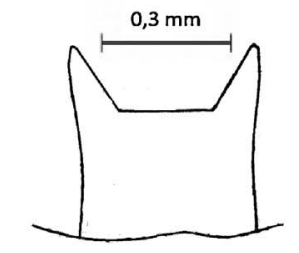

B
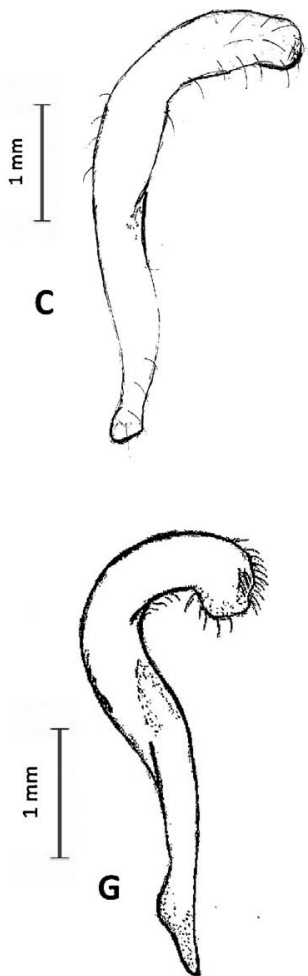
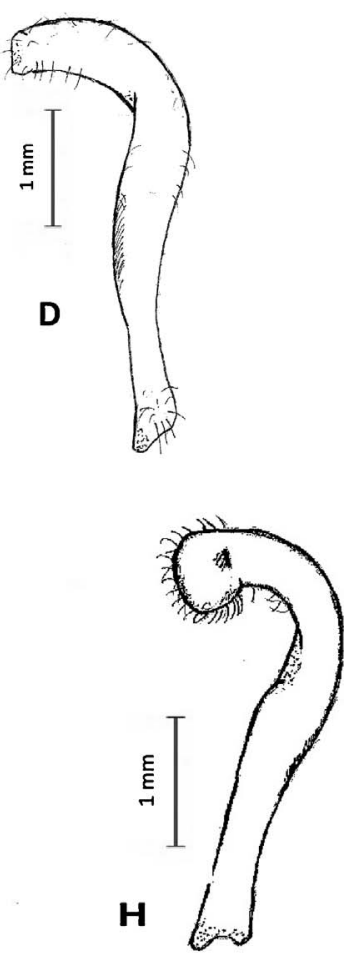

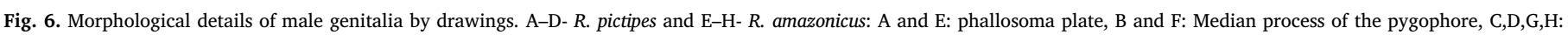
parameres. 

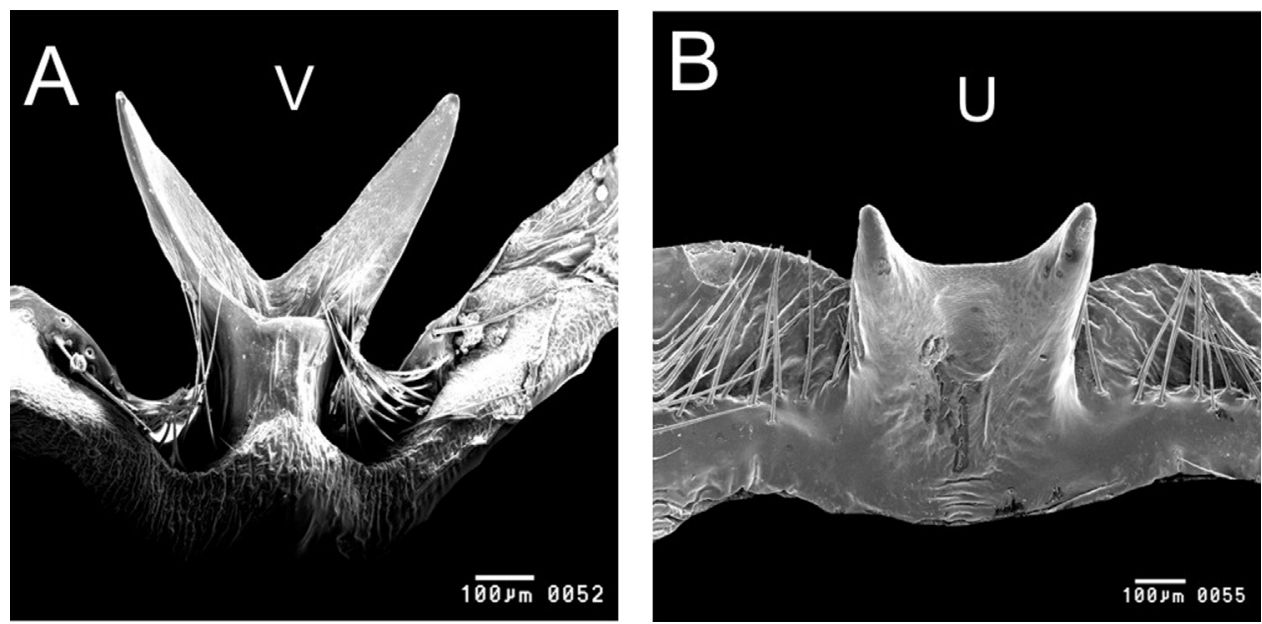

Fig. 7. Median process of the pygophore by SEM. A R. amazonicus; B- R.pictipes. V: format of pygophore; $\mathrm{U}$ : format of pygophore.
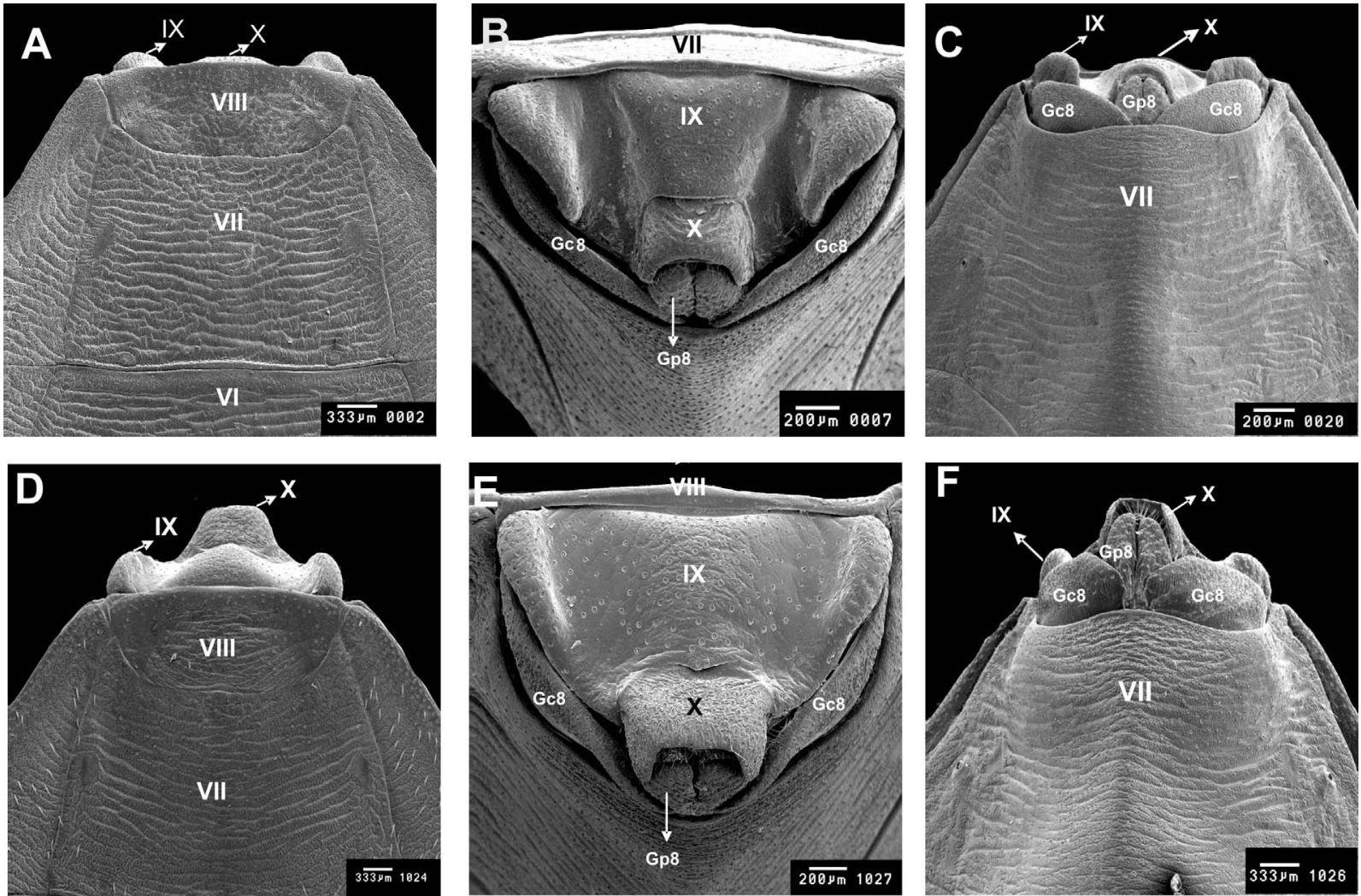

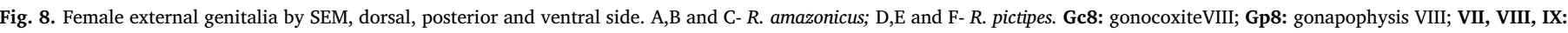
esternites; X: segment (Rosa et al., 2010).

the meso and metasternum, medially, there is a slit in $R$. amazonicus (Fig. 5B), which is absent on R. pictipes (Fig. 5D). The posterior margin of the metasternum of $R$. amazonicus is uniform in length, whereas on $R$. pictipes it is narrowed in the median portion (Fig. 5B,D).

\subsubsection{Abdomen}

The anterior margin of the process of urotergite I in $R$. amazonicus is evidently transversely grooved, what is not observed in $R$. pictipes. Just below the distal portion of the process of urotergite $\mathrm{I}$, there is a median conspicuous oval ridge with three pairs of subparallel ridges beside it in $R$. amazonicus, whereas in $R$. pictipes such structures are absent (Fig. 4A,B).

\subsubsection{Male genitalia}

The median processes of the pygophores present flat bifurcations, disposed in V-shape in R. amazonicus (Figs. $6 \mathrm{~F}, 7 \mathrm{~A}$ ) and in U-shape in R. pictipes (Figs. $6 \mathrm{~B}, 7 \mathrm{~B}$ ).

The parameres of $R$. amazonicus are markedly curved at distal half, with several setae at the apex (Fig. 6G,H), while the parameres of $R$. pictipes are only slightly curved, with few setae at apex (Fig. 6C,D)

The base of phallosoma plate in $R$. amazonicus is U-shaped and its apical margin is rectangular (Fig. 6E), while in R. pictipes, these portions are $\mathrm{V}$-shaped and rounded respectively (Fig. 6A).

\subsubsection{Female genitalia}

In the same plane of the dorsal view of the external female genitalia, only the terminal portions of the IX and X segments of $R$. amazonicus are seen (Fig. 8A), whereas in $R$. pictipes these two segments seem much larger and the $\mathrm{X}$ is very prominent (Fig. 8D). In the two species, the line dividing the VII and VIII segments are curved, but the lateral posterior 

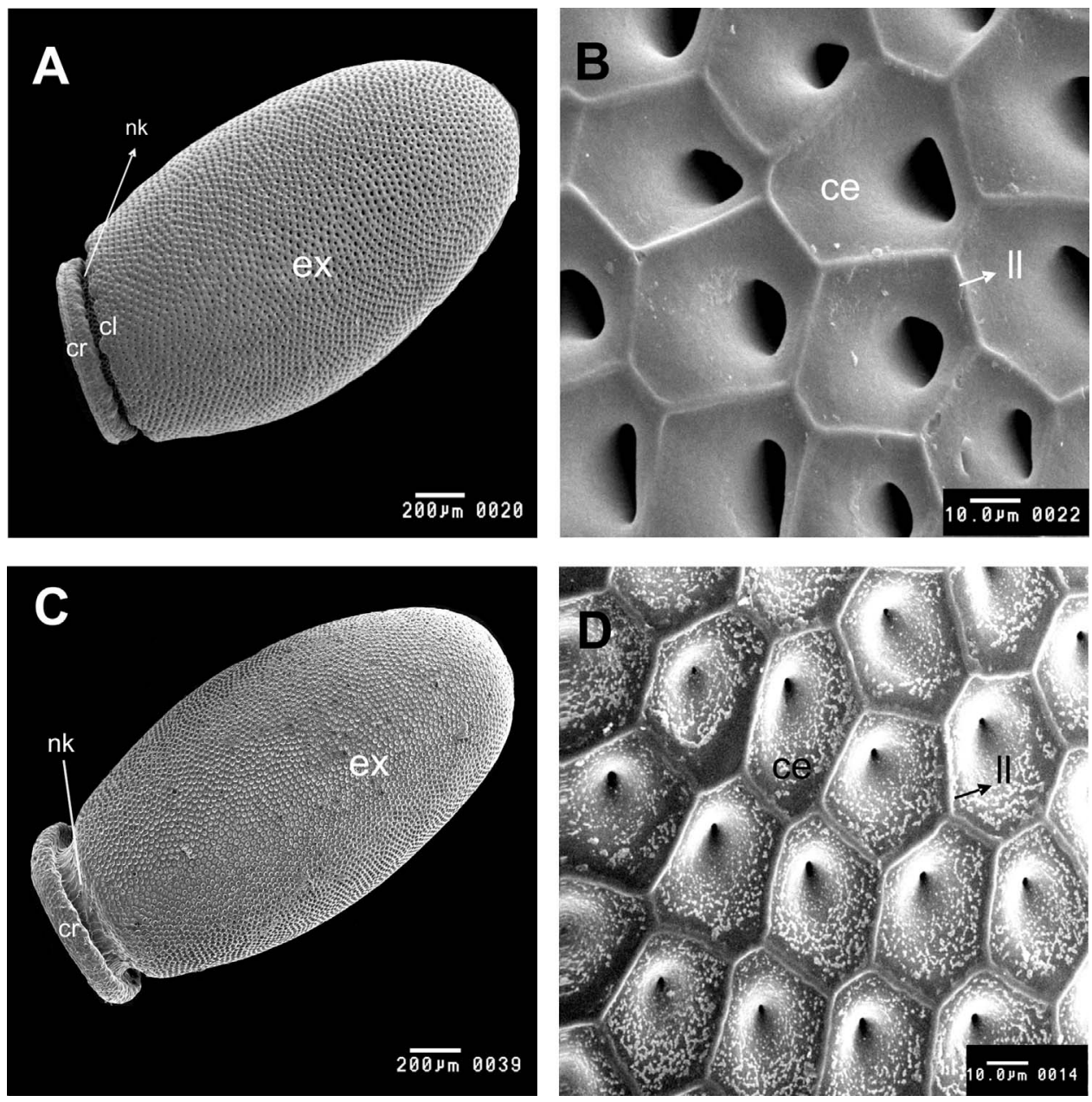

Fig. 9. Egg general vision and egg exochorion detail by scanning electron microscopy. A and B- $R$. amazonicus; C and D- R. pictipes. Cl: collar; cr: chorial rim; ex: exochorion; nk: neck; ce: exochorion cell; 11: limiting line.

Table 2

Distinguishing characters among ten species of Brazilian Amazon region.

\begin{tabular}{|c|c|c|}
\hline Species & Distinctive characters & References \\
\hline R. amazonicus & $\begin{array}{l}\text { Appearance not mottled, hemelytra do not reach the extremity of the female's abdomen and the bifurcation of median } \\
\text { processes of the pygophore bispinous is in the form of the letter V. }\end{array}$ & This work \\
\hline R. brethesi & Present rectangular spots of orange or red color on the connexivum. & Lent and Wygodzinsky (1979 \\
\hline R. marabaensis & $\begin{array}{l}\text { The second antennal segment is } 10.3 \text { times larger than the first. The scutellum is larger and includes two prominent } \\
\text { internal lateral carenas. }\end{array}$ & Souza et al. (2016) \\
\hline R. milesi & The male genitalia present a second process of the phallosoma. Divergent antennal tubercle with an apical denticle. & Valente et al. (2001) \\
\hline R. montenegrensis & $\begin{array}{l}\text { Anterior wings with well-demarcated veins, notable the Sc by a yellow tonality. Abdomen presents yellow spots } \\
\text { interposed with dark ones over the ventral abdomen lengthwise. }\end{array}$ & Rosa et al. (2012) \\
\hline R. paraensis & Presents the smaller length of the male $(10.5-11.0 \mathrm{~mm})$ and the female $(10.8-12.0 \mathrm{~mm})$ & Lent and Wygodzinsky (1979 \\
\hline R. pictipes & $\begin{array}{l}\text { Head an legs with general color pattern consisting of small irregular spots and dots, thus conspicuously mottled and } \\
\text { median processes of the pygophore bispinous in the form of the letter U. }\end{array}$ & $\begin{array}{l}\text { Lent and Wygodzinsky (1979) and this } \\
\text { work }\end{array}$ \\
\hline R. prolixus & $\begin{array}{l}\text { Anteocular region slightly over three times as long as postocular. Specimens distance between eyes dorsally larger } \\
\text { than width of eyes in dorsal view. }\end{array}$ & Lent and Wygodzinsky (1979) \\
\hline R. robustus & $\begin{array}{l}\text { Anteocular region about four times as long as postocular. Specimens distance between eyes dorsally smaller than, or } \\
\text { equal to, width of eye in dorsal view. }\end{array}$ & Lent and Wygodzinsky (1979) \\
\hline R. stali & Region anteocular up to 2.5 times greater than ocular post. & Galvão (2014) \\
\hline
\end{tabular}

*Species of Brazilian Amazon region according to Souza et al. (2016).

[or distal] extremities of the VII are short on R. amazonicus (Fig. 8A) and long in $R$. pictipes (Fig. 8D).

The posterior view of the IX segment shows two large depressions and two large flaps, both of which more pronounced in $R$. amazonicus (Fig. 8B) and smaller in R. pictipes (Fig. 8E).

The ventral view of the external female genitalia of $R$. amazonicus shows that the two gonocoxites VIII are curved along their entire length and drop-shaped, whereas on $R$. pictipes they are rectilinear at the upper portion of the central limit with the segment VII and the gonapophysis
VIII, curved at the posterior portion and larger than those of $R$. amazonicus (Fig. 8B,E). Also on the ventral view, the IX segment of $R$. amazonicus shows two deep depressions and two lateral flaps that can be seen on posterior view, and on $R$. pictipes the lateral flaps are smaller and partially covered by the segment VII (Fig. 8C,F). Another difference can be noted: the shape of the $\mathrm{X}$ segment is semi-circular on $R$. amazonicus and straight on the terminal portion on $R$. pictipes. It is easily noticeable by ventral view that on $R$. pictipes the $\mathrm{X}$ segment is much longer than the IX one, while on $R$. amazonicus the IX and X segments 


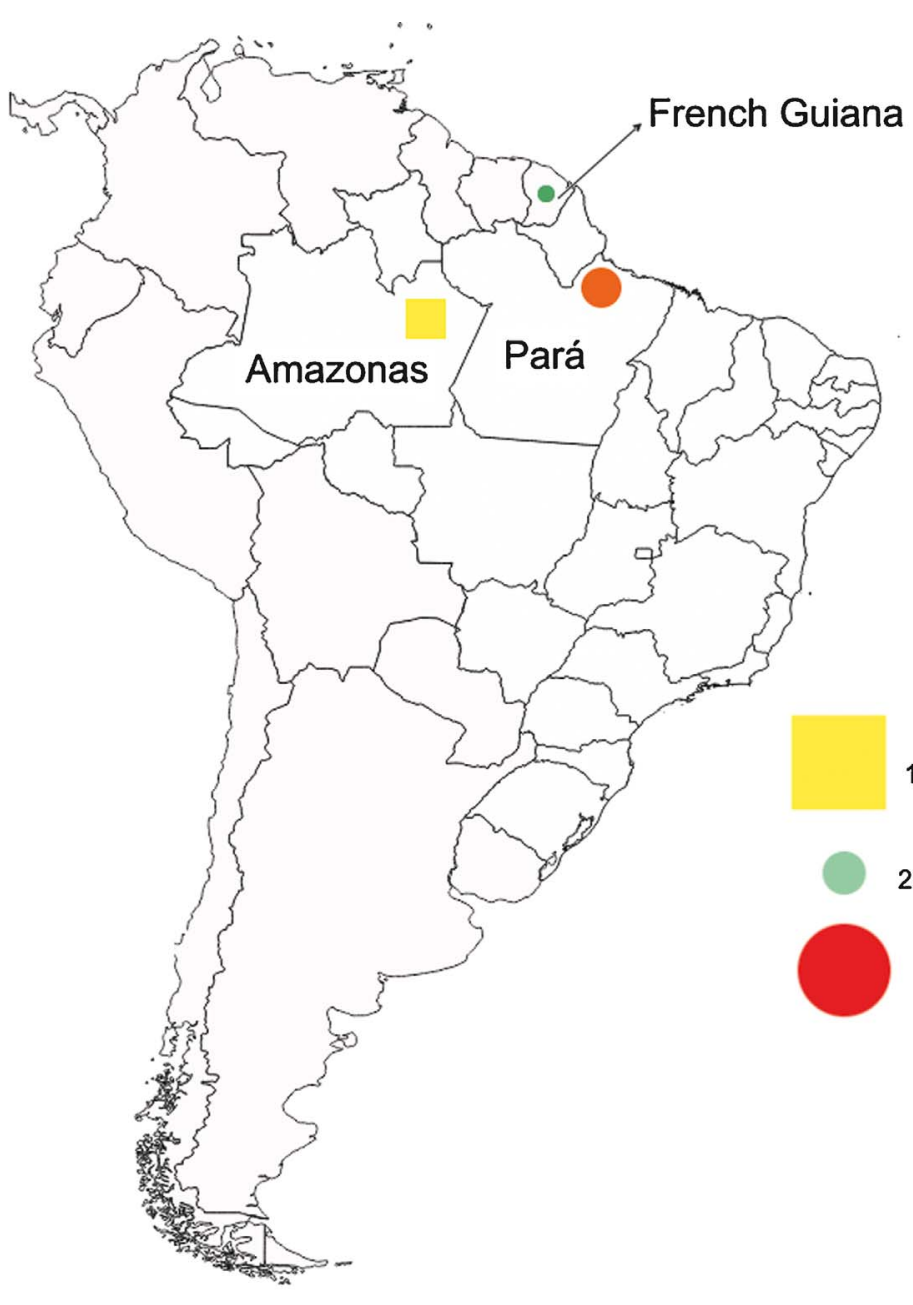

Fig. 10. Distribution of Rhodnius amazonicus. The yellow square and green circle indicates the first and second record of Rhodnius amazonicus from literature and the red circle indicates the new record of Rhodnius amazonicus in Breves, Pará state. (For interpretation of the references to colour in this figure legend, the reader is referred to the web version of this article.) have basically the same length (Fig. 8C,F).

\subsubsection{Eggs}

The eggs of $R$. amazonicus are longer (2.02 $\mathrm{mm}$ in length) and their opercular openings show different sizes $(0.44 \mathrm{~mm})$, when compared to those of $R$. pictipes ( $1.78 \mathrm{~mm}$ and $0.43 \mathrm{~mm}$ respectively)., The eggs of $R$. amazonicus present collar (Fig. 9A), which is absent in $R$. pictipes (Fig. 9C). Exocorial cells of both species are well delimited; however, the limiting line of the exocorial cells of $R$. amazonicus are considerably elevated (Fig. 9B), whereas in the case of $R$. pictipes they are slightly sulcate (Fig. 9D). The diameters of the follicular tubes also differ for the two species, being larger in R. amazonicus (Fig. 9B,D).

\section{Discussion}

Almeida et al. (1973) described R. amazonicus by comparing it with $R$. pictipes. They took into account the coloration, measurements of twelve head characters, seven thorax characters and three abdomen characters of the female holotype, presenting a total of eight figures. Subsequently, $R$. amazonicus was considered as a synonym of $R$. pictipes by Lent and Wygodzinsky (1979).

Twenty-three years later, however, $R$. amazonicus was revalidated. This was the result of comparative studies with $R$. pictipes using characters of the coxae, trochanter, femur, connexivum, female and male genitalia. The revalidation was illustrated with twenty one drawings and five optical microscopy images (Bérenger and Pluot-Sigwalt, 2002).

In the present study, it was found that the dorsal portion of the head of $R$. amazonicus and $R$. pictipes differs in demarcations of glabrous lines $1^{\circ}$ record from literature

$2^{\circ}$ record from literature

New record

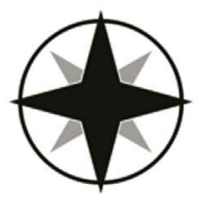

and clypeus; size and shape of genae and anteclypeus (Fig. 3). Scutellum and I urotergite process of $R$. amazonicus and $R$. pictipes are different (Fig. 4). They also differ from $R$. montenegrensis and $R$. robustus (Rosa et al., 2012).

Rhodnius amazonicus and $R$. pictipes differ in shape and size of the stridulatory sulcus and of the portion situated between the pro and mesosternum (Fig. 5).

Examination of the dorsal portion of the external female genitalia showed that IX and X segments are clearly smaller on $R$. amazonicus when compared to $R$. pictipes (Fig. 8A,D), a difference which can be noted on the ventral view too (Fig. 8C,F). On posterior view, differences were recorded on the anterior and lateral portions of the segment IX (Fig. 8B,E). The size and shape of the eighth gonocoxite are different, as well as the shape of segments IX and X on examination of the ventral portion (Fig. 8C,F).

Both median processes of the pygophores of R. amazonicus and $R$. pictipes are bifurcate. However, the bifurcation of $R$. amazonicus is in the form of the letter $\mathrm{V}$ and the $R$. pictipes of the letter $\mathrm{U}$ (Figs. $6 \mathrm{~B}, \mathrm{~F}, 7 \mathrm{~A}, \mathrm{~B}$ ).

The differences between eggs of $R$. amazonicus and $R$. pictipes are very clear on size, shape and general design (Table 1 ). The exocorial cells (Fig. 9B,D) are also clearly distinct.

By including a SEM of dorsal portions of head, scutellum, process of urotergite I, stridulatory sulcus, meso and metathorax, external female genitalia, median processes of pygophores and eggs, which were not observed in the description and redescription of $R$. amazonicus, this study has contributed to facilitating the identification of the species.

Among the characters measured the differences were significant between $R$. amazonicus and $R$. pictipes in thirteen male characters and 
fifteen female characters (Table 1 ).

Rhodnius amazonicus and $R$. pictipes occur in the North region of Brazil along with $R$. brethesi, $R$. marabaensis, $R$. milesi, $R$. montenegrensis, $R$. paraensis, $R$. prolixus, R. robustus and R. stali (Galvão, 2014; Souza et al., 2016). Because of this, the Table 2, which is a synopsis of the main characters used to distinguish them, was included.

Characteristics of the female external genitalia suggest that $R$. amazonicus may be grouped with $R$. milesi, $R$. pictipes, $R$. prolixus and $R$. stali (all from the North region of Brazil) as well as with $R$. domesticus Neiva and Pinto (1923), R. ecuadoriensis Lent and León (1958), R. nasutus Stål (1859) and $R$. neivai Lent (1953), due to the fact that the intersegmental suture between tergites VII and VIII is curved (Rosa et al., 2014). However, $R$. amazonicus distinguishes itself from the other nine species of the North region of Brazil in characters of the dorsal, posterior and ventral portions of the external female genitalia (Rosa et al., 2014) (Fig. 8).

The eggs of $R$. amazonicus present a lateral flattening, a neck, found in the other Rhodnius species, and the collar, also found in R. milesi, $R$. montenegrensis, $R$. neglectus and $R$. paraensis, but absent in $R$. brethesi, $R$. pictipes, $R$. prolixus, $R$. robustus and $R$. stali (Barata, 1981; Rosa et al., 2012). Nevertheless, evident characters in the exocorial cells of their eggs can distinguish these nine species of Rhodnius from the North region of Brazil (Table 2).

The eggs of $R$. amazonicus present a lateral flattening, a neck, found in the other Rhodnius species, and the collar, also found in R. milesi, $R$. montenegrensis, $R$. neglectus and $R$. paraensis, but absent in $R$. brethesi, $R$. pictipes, $R$. prolixus, $R$. robustus and $R$. stali (Barata, 1981; Rosa et al., 2012). Nevertheless, evident characters in the exocorial cells of their eggs can distinguish these nine species of Rhodnius from the North region of Brazil (Table 2). According to Carcavallo et al. (2000), Rhodnius species can be classified into five complexes, and they included $R$. amazonicus in the $R$. pictipes complex (Carcavallo et al., 2000).

\section{Conclusions}

Eleven characters of a male, a female and eggs of $R$. amazonicus were analyzed by SEM and seventeen were measured. Simultaneously, specimens of $R$. pictipes were similarly studied and measured. Twenty eight were used to illustrate the differences and differentiate these species.

It is worth noting that the identification of characters on the head, stridulatory sulcus, mesosternum, metasternum, scutellum, process of urotergite I, external female genitalia, pygophore and eggs made the distinction between $R$. amazonicus and $R$. pictipes possible. As only two encounters of $R$. amazonicus are reported, this contribution aims to report the third encounter of this species (Fig. 10), as well as to increase the number of morphological characters that distinguish $R$. amazonicus from $R$. pictipes.

\section{Funding}

CAPES Organization (Ministry of Education, Brazilian Government, Brazil), process number 23038.005285/2011-12, Programa ao Desenvolvimento Científico da Faculdade de Ciências Farmacêuticas do Campus de Araraquara da UNESP - PADC funding this study and
CNPq.

\section{Acknowledgement}

We thank to our friend teacher Dr. José Maria Soares Barata, who left us on September 9, 2016, for all his efforts in the study of Triatominae and the example of his life.

\section{References}

Almeida, F.D.B., Santos, E.I., Sposina, G., 1973. Triatomíneos da Amazônia III. Acta Amazon. 3, 43-46.

Bérenger, J.-M., Pluot-Sigwalt, D., 2002. Rhodnius amazonicus Almeida, Santos \& Sposina, 1973, Bona Species, Close to R. pictipes Stél, 1872 (Heteroptera, Reduviidae, Triatominae). Mem. Inst. Oswaldo Cruz. 97, 73-77.

Barata, J.M.S., 1981. Aspectos morfológicos de ovos de Triatominae II - Características macroscópicas e exocoriais de dez espécies do gênero Rhodnius Stål, 1859 (Hemiptera - Reduviidae). Rev. Saude Publica 15, 490-542.

Carcavallo, R.U., Jurberg, J., Lent, H., Noireau, F., Galvão, C., 2000. Phylogeny of the Triatominae (Hemiptera: Reduviidae): proposals for taxonomic arrangements. Entomol. Vectores 7, 1-99.

Chagas, C., 1909. Nova Tripanozomiaze humana. Estudos sobre a morfolojia e o ciclo evolutivo do Schizotrypanum cruzi n. gen., n. sp., ajente etiolojico de nova entidade morbida do homem. Mem. Inst. Oswaldo Cruz 1, 159-218.

De Geer, C., 1773. Mémoires pour servir à lh'istoire des insectes, vol. 3. Hesselberg, Stockholm, pp. 696.

Galvão, C., 2014. Vetores da doença de Chagas no Brasil [online]. Zoologia: guias e manuais de identificação. Sociedade Brasileira de Zoologia, Curitiba, pp. 289.

Jurberg, J., Rocha, D.S., Galvão, C., 2009. Rhodnius zeledoni sp. nov. afim de Rhodnius paraensis Sherlock Guitton \& Miles. 1977; (Hemiptera, Reduviidae, Triatominae). Biota Neotrop. 9, 123-128.

Lent, H., Wygodzinsky, P., 1979. Revision of the Triatominae (Hemiptera, Reduviidae) and their significance as vectors of Chagas' disease. Bull. Am. Mus. Nat. Hist. 163, 123-520.

Mendonça, V.J., Alevi, K.C.C., Pinotti, H., Gurgel-Golçalvez, R., Pita, S., Guerra, A.L., Panzera, F., Araujo, R.F., Azeredo-Oliveira, M.T.V., Rosa, J.A., 2016. Revalidation of Triatoma bahiensis Sherlock \& Serafim, 1967 (Hemiptera: Reduviidae) and phylogeny of the T. brasiliensis species complex. Zootaxa 4107, 239-254.

Pinto, C., 1926. Classificação dos Triatomideos (hemípteros-heteropteros hematophagos). Sci. Med. (Porto Alegre) 4, 485-490.

Pinto, C., 1927. Classification de genres d' Hémiptères de la famille Triatomidae (Reduvidioidea). Boletim Biologico de São Paulo 8, 103-114.

Rosa, J.A., Freitas, S.C.M., Malara, F.F., Rocha, C.S., 2010. Morphometry and morphology of the antennae of Panstrongylus megistus Burmeister, Rhodnius neglectus Lent, Rhodnius prolixus Stal and Triatoma vitticeps Stal (Hemiptera: Reduviidae). Neotrop. Entomol. 39, 214-220.

Rosa, J.A., Rocha, C.S., Gardim, S., Pinto, C.M., Medonça, V.J., Filho, J.C.R., Carvalho, E.O.C., Oliveira, J., Nascimento, J.D., Cilense, M., Almeida, C.E., 2012. Description of Rhodnius montenegrensis sp.n. (Hemiptera: Reduviidae: Triatominae) from the state of Rondônia Brazil. Zootaxa 3478, 62-76.

Rosa, J.A., Mendonça, V.J., Gardim, S., Carvalho, D.B., Oliveira, J., Nascimento, J.D., Pinotti, H., Pinto, M.C., Cilensi, M., Galvão, C., Barata, J.M.S., 2014. Study of the external female genitalia of 14 Rhodnius species (Hemiptera, Reduviidae, Triatominae) using scanning electron microscopy. Parasit. Vect. 7, 1-10.

Rosa, J.A., Justino, H.H.G., Nascimento, J.D., Mendonça, V.J., Rocha, C.S., Carvalho, D.B., Falcone, R., AzeredoOliveira, M.T.V., Alevi, K.C.C., Oliveira, J., 2017. A new species of Rhodnius from Brazil (Hemiptera, Reduviidae, Triatominae). ZooKeys 675, $1-25$.

Sherlock, I.A., Guitton, N., Milles, M., 1977. Rhodnius paraensis espécie nova do Estado do Pará, Brasil (Hemiptera, Reduviidae, Triatominae). Acta Amazon. 7, 71-74.

Souza, E.S., Von Atzingen, N.C.B., Furtado, M.B., Oliveira, J., Nascimento, J.D., Vendrami, D.P., Gardim, S., Rosa, J.A., 2016. Description of Rhodnius marabaensis sp. n. (Hemiptera Reduviidade, Triatominae) from Pará State, Brazil. Zookeys 621, 45-62.

Valente, V.C., Valente, S.A.S., Carcavallo, R.U., Rocha, D.S., Galvão, C., Jurberg, J., 2001. Considerações sobre uma nova espécie do gênero Rhodnius Stål, do estado do Pará, Brasil (Hemiptera, Reduviidae, Triatominae). Entomol. Vectores 8, 65-80. 